\section{Royal Gardens of Queen Anne}

A NUMBER of interesting manuscripts belonging to Lieut.-Colonel H. E. Disbrowe-Wise have lately been abstracted by MIr. F. J. Chittenden ( $J$. Roy. Hort. Soc., 64, Pt. 10; October 1939). They relate to the part played by Henry Wise in tho upkeep and rearrangement of the Royal Gardens in the reign of Queen Anne. Wise and his partner, George London, were the proprietors of the great Brompton Nursery, and directed the establishment of most of the large gardens of England at the beginning of the eighteenth century. They were responsible for the introduction of French influence in garden design, but they evidently eliminated some of the frivolities of Versailles horticulture, and used only the stateliest elements in the spacious parks, terraces and avenues of Hampton Court and other Royal demesnes. Details and costs of the upkeep are rovealed by the manuscripts. Henry Wiso received $£ 1,600$ a year from 1702, for the upkeep of Hampton Court, the gardens at Windsor and the plantations at Kensington. A catalogue of the varieties of wall fruit reveals some affinity with modern names, and an important side of garden activity is shown by a description of five new pears which bore fruit in the year 1715. Each of the new varieties appears to have been "very rich and melting", and doubtless played its part in the general improvement the results of which we enjoy to.day.

\section{National Central Library}

WINTER is the reading man's season. Then, as the Student says in Goethe's "Frust":

"the pleasures of the mind Bear us from book to book, from page to page.

With them the winter nights grow kind and bright, And overy limb is warmed with happy life."

But if we want unusual books, such as, say, Bolingbroke's idea of " "Patriot King", can we get them? The answer is given by the great National Central Library in Mralet Place, London. It lends books through the local libraries and regional bureaux and has access to 21 million volumes in other institutions. It can do work of national importance in helping research in science and medicine. Somo irreplaceablo matter has been removed to Hemel Hempstead, but the non-bibliographical books remain at the London headquarters. The latest report of the Library shows that it lent during 1938-39 more than 21,000 books to urban libraries, and more than 12,000 to country ones. The 'outlier' libraries, from which readers can borrow through the National Central Agency, now include, wo notice, the British Postgraduate Nedical School and the Library of Radiological Periodicals (Dr. Bernard Leggett).

\section{Health in British India during 1937}

Tre state of the public health in British India and some of the Indian States during 1937 is dealt with in the recently issued "Annual Report of the Public Health Commissioner with the Government of India for 1937" (Government of India Press, New Delhi, 1939. Price Rs. 3 or 5s.). The mid-year estimated population for British India was 272,406,436, an increase of more than three and a quarter millions com. pared with the previous year. The birth-rate was 34.5 , and the death-rate 22.4 per mille, each a slight decrease over the previous year, and tho infantile death-rate par 1,000 live births was 161.7. Plague mortality, with 28,169 deaths, was appreciably higher than in 1936, but deaths duo to eholera and smallpox, $99,05 t$ and 54,810 respectively, showed large decreases, so that there was a total reduction of more than 90,000 deaths from these epidemic diseases. With regard to plague, it is romarked that within recent years the fatality-rate has considerably decreased, and that the disease is often so mild that patients remain at work during the attack. Nalaria and respiratory diseases cause the largest mortality; roughly about 1,000 people dio from malaria overy day throughout the year. Dysentery and diarrhœa caused 267,479 deaths, or more than two and a half times the number of cholera deaths. With regard to vaccination and its protective power against small. pox, figures show that the greater the number of vaccination 'marks' the smaller is the caso mortality rate, and that mortality is much the highest among those having 'no marks', which may be presumed to mean absence of vaccination. The volume also contains much information on maternity and child welfare and on the research work of various colleges and institutes.

\section{Animal Welfare}

SINCE 1931 the Universities Federation for Animal Welfare (formerly the University of London Animal Welfare Society) has published annually the Animal Year Book, a journal which has contained many useful hints on the care of animals and given evidence of strenuous propaganda on behalf of the woll-being of wild and domesticated animals. The Year Book has now been replaced by $U F A W$ Quarterly Journal, which continues the policy of its predecessor but affords means of closer contact between the members of the Federation and others interested in its benevolent activities. Articles of general interest in the first number discuss the ideal pet-shop and a population study of rabbits. A strong and justifiable plea is made for the better regulation of the importation and trade in Nediterranean tortoises, of which some 150,000 are said to be imported into Great Britain annually, often under the most objectionablo conditions. It may be added, for the information of readers in whose family circlo a tortoise makes its appearance, that pamphlets on the care of these pets have been issued by both the English and Scottish Societies for the Prevention of Cruelty to Animals.

\section{Cave Animals}

W'ITH the appearance of "Pars 14" (published in 1938 but only recently received by NATURE) the great "Animalium Cavernarum Catalogus", compiled by Dr. Benno Wolf and published by Dr. W. Junk, reaches completion. Anyone who has followed the 